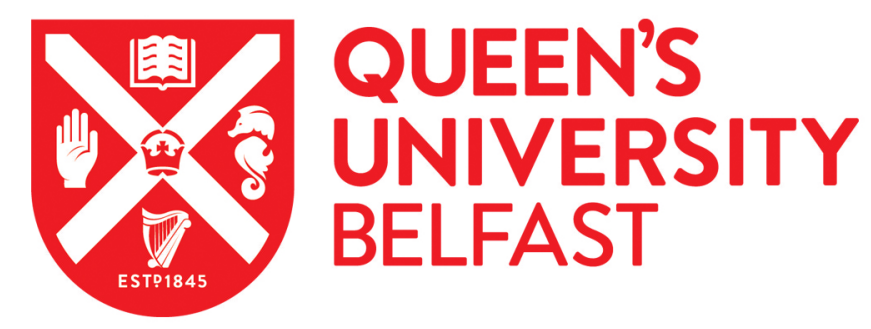

\title{
Why Are Some Subsidiaries of Multinationals the Source of Novel Practices while Others Are Not? National, Corporate and Functional Influences
}

Edwards, T., Sanchez-Mangas, R., Belanger, J., \& McDonnell, A. (2015). Why Are Some Subsidiaries of Multinationals the Source of Novel Practices while Others Are Not? National, Corporate and Functional Influences. British Journal of Management, 26(2), 146-162. https://doi.org/10.1111/1467-8551.12090

Published in:

British Journal of Management

Document Version:

Peer reviewed version

Queen's University Belfast - Research Portal:

Link to publication record in Queen's University Belfast Research Portal

\begin{abstract}
Publisher rights
(C) 2015 British Academy of Management.

This is the peer reviewed version of the following article: Edwards, T., Sanchez-Mangas, R., Bélanger, J. and McDonnell, A. (2015), Why Are Some Subsidiaries of Multinationals the Source of Novel Practices while Others Are Not? National, Corporate and Functional Influences. British Journal of Management, 26: 146-162, which has been published in final form at http://onlinelibrary.wiley.com/doi/10.1111/14678551.12090/abstract. This article may be used for non-commercial purposes in accordance with Wiley Terms and Conditions for SelfArchiving.

General rights

Copyright for the publications made accessible via the Queen's University Belfast Research Portal is retained by the author(s) and / or other copyright owners and it is a condition of accessing these publications that users recognise and abide by the legal requirements associated with these rights.
\end{abstract}

\section{Take down policy}

The Research Portal is Queen's institutional repository that provides access to Queen's research output. Every effort has been made to ensure that content in the Research Portal does not infringe any person's rights, or applicable UK laws. If you discover content in the Research Portal that you believe breaches copyright or violates any law, please contact openaccess@qub.ac.uk. 


\title{
Why are some subsidiaries of multinationals the source of novel practices while others are not? National, corporate and functional influences
}

Tony Edwards, Rocio Sanchez-Mangas, Jacques Bélanger and Anthony McDonnell

For full paper see: Edwards, T., Sanchez-Mangas, R., Belanger, J. and McDonnell, A. (2015) 'Why are some subsidiaries of multinationals the source of novel practices while others are not? National, corporate and functional influences', British Journal of Management, 26 (1): 146-162

\begin{abstract}
It has frequently been argued that multinational companies are moving towards network forms whereby subsidiaries share different practices with the rest of the company. This paper presents largescale empirical evidence concerning the extent to which subsidiaries input novel practices into the rest of the multinational. We investigate this in the field of human resources through analysis of a unique international dataset in four host countries - Canada, Ireland, Spain and the UK - and address the question of how we can explain variation between subsidiaries in terms of whether they initiate the diffusion of practices to other subsidiaries. The data supports the argument that multiple, rather than single, factor explanations are required to more effectively understand the factors promoting or retarding the diffusion of HR practices within multinational companies. It emerges that national, corporate and functional contexts all matter. More specifically, actors at subsidiary level who seek to initiate diffusion appear to be differentially placed according to their national context, their place within corporate structures and the extent to which the HR function is internationally networked.
\end{abstract}

\section{Keywords}

Comparative, diffusion, HR practices, multinational companies, subsidiaries, transfer. 


\section{Introduction}

Multinational companies (MNCs) are commonly argued to be moving towards network forms in which subsidiaries take on key roles, sharing practices with the rest of the company (Birkinshaw, 1997; Birkinshaw, Hood and Jonsson, 1998; Frost and Zhou, 2005; Govindarajan and Ramamurti, 2011; Nohria and Ghoshal, 1997; Veliyath and Sambharya, 2011). Persistent national diversity in the context in which organizations operate presents the opportunity for MNCs to capitalise on local patterns of distinctive practices and spread these internationally. As Cantwell and Zhang put it, given that expertise 'is in part location-specific as well as firm-specific, the MNC has come increasingly to draw upon a diversified locational portfolio of capabilities' (2009: 46). There is growing evidence that the competitive position of MNCs can be enhanced through the effective utilization of knowledge developed in different parts of their worldwide operations rather than adopting an ethnocentric attitude (e.g. Doz et al., 2001; Minbaeva, 2007). Realising the benefits of the diverse capabilities and knowledge that reside within the firm is, however, far from straightforward (Gupta and Govindarajan, 2000; Whitley, 2009).

The diffusion of human resource (HR) practices is a key part of MNCs' attempts to fully exploit at the international level the diverse capabilities and knowledge that they possess at subsidiary level. HR activities such as training and development are central to the development of skilled and knowledgeable staff, for example, while others such as communication and consultation, are key elements of management style (e.g. Bjorkman and Lervik, 2007). Whilst strategically important, HR practices are also strongly shaped by firms' context, arguably more so than practices in other areas of management (Rosenzweig and Nohria, 1994), giving them a degree of 'stickiness' (Jensen and Szulanski, 2004; Szulanski, 1996).

In this paper we explore the diffusion of HR practices from the foreign operations of MNCs to the rest of the firm. This has been termed 'reverse diffusion' (RD) in the sense that the direction of diffusion is inverted from that which is the main focus of research concerning MNCs. This has been broken down into 'strict' RD whereby practices from subsidiaries are transferred to the domestic 
operations and 'horizontal' diffusion (HD), where practices from subsidiaries are diffused to other foreign operations (Boussebaa et al., 2014). For simplicity, we use the term RD to capture both elements of this phenomenon. The RD literature has almost entirely employed the case study research method, which has revealed much about how it occurs and the importance of actors' interests and power in either initiating or blocking RD (see, for example Edwards et al., 2005; Edwards and Tempel, 2010). This scholarship has also suggested that RD is promoted by certain corporate characteristics, such as an international growth strategy focused on achieving synergies between worldwide operations and the presence of international management structures (Edwards, 1998). However, there are two main gaps in this literature. Theoretically, the literature has generated only the most basic understanding of how national context shapes the position of MNC subsidiaries to initiate diffusion. Empirically, there are rather few studies that distinguish between the various directions that diffusions can take and, amongst those that do, hardly any quantitative evidence concerning the factors which promote or retard RD or draw on data from multiple countries (Michailova and Mustaffa, 2012).

This paper helps fill these gaps by examining how the national context of the subsidiary creates variation in the potential for subsidiaries to initiate diffusion within MNCs through analysis of a unique, representative, cross-country dataset. We consider the role of the national context alongside other explanations for variation in the incidence of RD and argue that the national, corporate and functional contexts all matter, demonstrating the benefits in adopting a multiple, rather than single, factor explanation (Hansen and Lovas, 2004). Specifically, actors at subsidiary level who initiate diffusion are differentially placed according to their national context, their place within corporate structures and the extent to which the HR function is internationally networked.

The four countries that we study - Canada, Ireland, Spain and the UK - have important features that make them interesting contexts in which to investigate RD. All have established property rights and markets, pre-requisites for a substantial amount of foreign direct investment (FDI) (Murtha and Lenway, 1994). Despite some institutional differences, they all allow MNCs a considerable degree 
of freedom in experimenting with new practices. From the 1980 s onwards the UK took a decisive 'liberal' turn towards a deregulated labour market and a significant weakening of organised labour. The Canadian economy is characterised by similarly liberal labour market structures and, notwithstanding the presence of industrial relations (IR) institutions above the level of the firm through national level coordination, Ireland also shares many of these characteristics. The institutional differences are apparently greater between these three countries and Spain, which possesses stronger employment protection laws (Amable, 2003) and a dual channel IR system of worker representation of works committees and unions (Martinez Lucio, 1998). However, in reality these bodies and practices are malleable in the hands of big companies, thus providing considerable flexibility to MNCs in Spain in devising novel practices (Quintanilla, Susaeta and Sánchez-Mangas, 2008; Quintanilla, Belizón, Susaeta, and Sánchez-Mangas, 2009). Consequently in all four countries MNCs have substantial scope for experimentation with distinctive practices. This is an important pre-condition for the subsidiaries to exert influence within the wider MNC. Yet, the national contexts vary in other respects, particularly the position that each economy occupies within the major flows of cross-border economic activity, a point which we develop in the next section.

\section{National, Corporate and Functional Influences}

A commonly used approach of analysing transfer within MNCs focuses on the notion of 'institutional distance'. This approach seeks to measure the degree of difference between the regulative, normative and cognitive dimensions of institutions across borders (Xu and Shenkar, 2002) and has been used to explain why transfer does or does not occur between two countries (for a review, see Ferner, Edwards and Tempel, 2012). Our aim is not to compare pairs of countries in which one is the donor and the other is the recipient but rather to compare the extent to which four countries contain donor units. Thus instead of focussing on the institutional distance approach, we adopt an eclectic approach drawing on three bodies of theory. The first relates to the position of each country within the major flows of cross- 
border economic activity, particularly FDI (Dicken, 2011). The second focuses on the way in which MNCs are fragmenting their activities across countries resulting in internationally integrated production (e.g. Buckley, 2011). The third concerns the ways in which the HR function is characterised by effective networks that are capable of transferring different practices across the firm (e.g. Dickmann and MullerCarmen, 2006). We take these in turn, building hypotheses from each.

\section{Position in the Global Economy}

It is well established that countries play different roles within the global economy and that this affects the dynamics of transfer within MNCs. As Almond (2011: 534) puts it, the dissemination of knowledge within global firms is 'dependent on the possibilities and supports offered by national and regional business systems'. Hansen and Lovas (2004) show 'intra-corporate competence transfers' are influenced by teams in one part of an MNC approaching other teams which they know. We contend that a key factor shaping who is well-connected within the firm concerns the position of the country within the major flows of international economic activity (Barrett, Cooper and Jamal, 2005; Boussebaa, Sturdy and Morgan, 2014). Countries that are host to a major financial and business centre occupy a more central or 'core' position within the firm since this creates multiple channels through which firms within the country can connect with those outside. Accordingly, Boussebaa et al's (2014) study of international consulting firms found that knowledge transfer flowed from the offices in the largest consulting markets, with those in other countries finding themselves as recipients but not donors in this process. In other words, the process of knowledge transfer was 'shaped by the wider global geopolitical economy' (2014: 1237). In a similar vein, Dicken (2011: 45-46) shows how the key 'growth axis' within Europe covers parts of the UK, Belgium, eastern France, Germany and northern Italy but excludes some countries whose economies performed well in the 1990s and early 2000s (e.g. Ireland and Spain). Even those who argue that the contemporary phase of globalisation has novel elements acknowledge that 'this does not mean that specific sites of corporate activity become irrelevant' (Sklair, 2001: 74). Overall, this 
suggests that MNC subsidiaries located in countries that are central to the major flows of economic activity are more favourably placed to be the source of RD.

In addition to the institutional environments all providing a degree of flexibility to MNCs, Britain, Canada, Ireland and Spain also share the characteristic of being major recipients of FDI. However, their position within the international economy differs. The UK has a long history of FDI, being the home of many of the earliest MNCs with the British Empire providing a supportive structure for internationalisation, and being highly open to inward FDI. Today, the UK receives the second largest share of the stock of inward FDI and is the second largest outward investor (United Nations, 2012). Moreover, within internationally networked firms it has often been accorded strategically important roles. It is the location of many regional HQs of MNCs originating outside the EU, partly influenced by London holding the 'pre-eminent position in European financial geographies' (Faulconbridge, 2004: 235) in which there are limited regulatory barriers and the presence of a part of the global managerial elite (Desai, 2009; Heenan, 1979; Sullivan, 1992). We view the influence of the British economy and the position of UK subsidiaries within networked MNCs as affording British managers scope to make their operations an 'important centre of gravity' within the firms and to spread their 'distinctive capabilities' elsewhere (Edwards et al., 2005: 1262). Consequently, we use the UK as a counterpoint in developing our country-specific hypotheses.

Like the UK, Canada has a long history of FDI. Its position within MNCs is different, however, owing to its relationship with the dominant US economy (Arthurs, 2000, 2009). Canadian operations are less commonly the centre of regional hubs of networked MNCs while the country does not possess a financial or business centre like London. These factors may limit the influence of Canadian subsidiaries within MNCs. A factor that may compensate for this is that the Canadian operations are often closely tied to those in the US, for good or otherwise, and this geographical proximity (Rugman and D'Cruz, 1993; Rugman and Oh, 2012) and 'embeddedness' in the same regional trading block is often reflected in regional corporate structures. Furthermore, for some time Canadian public policies have facilitated 
FDI and encouraged Canadian subsidiaries to gain more strategic roles within foreign MNCs (Birkinshaw and Hood, 1998), thereby increasing the scope for them to contribute to the diffusion of distinctive practices to MNC operations. Owing to these competing factors we hypothesise that: H1a: There will be no significant difference between British and Canadian operations as sources of reverse diffusion.

Ireland is more distinct compared to the UK and Canada, with Irish industrial development a more recent phenomenon. It was not until the 1960s and the pursuit of an open, free-market, outward looking growth strategy that industrial development truly commenced (O'Malley, 1992; Buckley and Ruane, 2006). Consequently, FDI growth has been quite recent, with much of it occurring off the back of a distinctive industrial policy of actively encouraging investment by foreign, manufacturing-based MNCs through financial subsidies and a low rate of corporation tax (Gunnigle and McGuire, 2001). While the type of FDI became more varied in the last few decades - some strategic functions were located there as Irish subsidiaries sought to move up the internal value chain - the character of FDI in Ireland has predominantly been as an export platform for relatively cheap production (Barry, 2004; McDonnell, Lavelle and Gunnigle, 2014). Accordingly, Ireland has a more limited FDI profile than the UK. Combined with the economy being much smaller and therefore less central to the financial and business elite (Yang, Mudambi and Meyer, 2008), the ability of subsidiary actors to generate interest in their practices amongst the rest of the MNC operations is constrained. We therefore propose that:

H1b: The British operations of MNCs will more commonly be the source of reverse diffusion than subsidiaries in Ireland.

FDI into Spain has also been a relatively recent development, expanding rapidly following the country's entrance into the EU. As argued above, Spain is not central to the major 'growth axis' within Europe (Dicken, 2011). One distinguishing characteristic of FDI in Spain, which is arguably linked to this lack of centrality, is that it is focussed on providing services to the domestic market (Clifton, DiazFuentes and Ruiz, 2011) while another is that MNCs in Spain have pursued strategies of accessing a 
distinctive market through acquisitions (Campa and Guillen, 1995). We might expect these features to lead to subsidiaries being more commonly managed in an 'arms-length' way. The finding that those running Spanish subsidiaries are subject to less 'social' control than their counterparts in other developed economies (Edwards, Tregaskis, Collings, Jalette and Susaeta, 2013) can be understood in this way, which may also be the result of language and cultural differences. Thus we propose that:

H1c: The British operations of MNCs will more commonly be the source of reverse diffusion than those in Spain.

\section{Internationally Integrated Production in MNCs}

Dicken (2011: 121-155) conceives MNCs as 'networks within networks', establishing the distinction between the internal networks of production and the externalized relationships with other firms as part of global production networks. We focus on the former, the interconnections within the firm. Some national subsidiaries may be independent or 'stand-alone', with their own domestic supply

chains and selling products straight to the market. However, it appears that many MNCs are developing internationally integrated processes of production or service provision whereby national operations increasingly supply each other (e.g. Buckley, 2011; Edwards, 2011; Grossman et al., 2003; Rangan and Sengul, 2009).

The relationship between internationally integrated forms of production and RD is multifaceted. It may be that the distinct role of each site created by a high level of integration means that subsidiaries are doing such different things that the scope for diffusion is limited (e.g. Wilkinson, Gamble, Humphrey, Morris and Anthony, 2001). Alternatively, there may be much scope for practices to be transferred and that the intra-firm trading creates channels through which this occurs (Edwards, 2000; Hakanson and Nobel, 2001; Holtbrugge and Mohr, 2011), a form of what Bjorkman and Lervik (2007) call 'interaction ties'. Thus the role of a subsidiary in relation to others in terms of knowledge inflows and outflows is associated with product flows within the MNC (Gupta and Govindarajan, 2000; Harzing 
and Noorderhaven, 2006). A particularly important case is where subsidiaries are supplying others since it is plausible that these flows of components or services facilitate corresponding flows of practices from that subsidiary to other parts of the firm, be they other foreign subsidiaries or operations in the home country. Being the recipient of components or services may also engender inter-subsidiary linkages that promote RD. Thus we hypothesise that:

H2a: Subsidiaries with trading linkages with other parts of the network are most likely to engage in reverse diffusion.

A second aspect of integrated production networks that may shape RD is the workforce characteristics of subsidiaries. If subsidiaries are inter-dependent, performing different functions from one another, then it follows that the mix of occupational groups and skill levels will differ. As Ferner, Belanger, Tregaskis, Morley and Quintanilla (2013) put it: 'host economies occupy distinctive positions in the international division of labour - as reservoirs of cheap and/or flexible labour, sources of primary inputs, springboards to wider continental markets, repositories of scarce and high-end skills and knowhow'. We draw a distinction between operations that have a highly skilled workforce which gives them a distinguishing and elevated position in the network and those subsidiaries with a predominantly lowskilled workforce that is imitable and confers a lower status (Edwards, 2011). Accordingly, Harzing and Noorderhaven (2006) link the capabilities of a subsidiary to its role in initiating diffusion. Following this logic, the distinct roles of sites that give rise to these differences in terms of workforce characteristics may limit the scope for diffusion since some practices have limited applicability across different groups of employees. Where there is scope for practices to operate across different subsidiaries we might expect the flow to be more commonly from those operations with a high-skilled workforce. This leads us to propose that:

H2b: Subsidiaries with highly skilled workforces are those most likely to engage in reverse diffusion. 


\section{HR Networks in MNCs}

The third category focuses on 'the richness of transmission channels' (Gupta and Govindararjan, 2000) in the HR function. Szulanski (1996) argued that the 'stickiness' of practices could partly be overcome were the parent firm to 'foster closer relationships between organizational units, and systematically understand and communicate practices' (1996: 37). Our focus is on the degree to which HR managers across the MNC are part of a network. Previous research highlighted the extent to which the HR function is characterised by a network capable of transferring knowledge across borders and how this can be crucial in the status of the HR function within the management structure of an MNC (Dickmann and Muller-Carmen, 2006). Additionally, the literature has shed some light on the struggles firms have in organizing across borders (Boussebaa, 2009) and the 'integrating modes' that MNCs use to coordinate their activities, highlighting the use of both 'information-based' and 'people-based' modes (Kim, Park and Prescott, 2003).

Concerning the nature of particular mechanisms at the level of the HR function, previous analysis has identified various 'organizational conduits' through which RD can occur. Some of these can be thought of as 'procedural-based' mechanisms, including specialist HR information systems (Boussebaa et al., 2014; Edwards, Edwards, Ferner, Marginson and Tregaskis, 2010). These appear to be effective in storing codifiable knowledge and may operate in conjunction with virtual groups or task forces where communication between cross-country actors occurs electronically. Other mechanisms are 'people-based', such as the 'repatriation' of staff who have spent time in the foreign subsidiaries (e.g. Furuya, Stevens, Bird, Oddou and Medenhall, 2008; Lazarova and Tarique, 2005; Oddou, Osland and Blakeney, 2008; Collings, McDonnell, Gunnigle and Lavelle, 2010). These are well attuned to handling tacit knowledge, the effective transfer of which requires face-to-face contact. Some practices require both codifiable and tacit knowledge to be communicated if transferred practices are to operate effectively so 'procedural' and 'people' based mechanisms should be seen as complements not as substitutes. On this basis we propose that: 
H3: Subsidiaries within MNCs that possess a strong network consisting of multiple crossborder communication mechanisms within the HR function are those in which reverse diffusion is most likely to occur.

\section{Method}

The paper is based on an innovative project, using comparative, parallel national surveys of MNCs operating in four countries in which the research instrument was created collaboratively. Each survey was based on the most comprehensive listing of MNCs that has been constructed to date in each country. Strong emphasis was put on this stage because developing accurate, up-to-date population listings is often insufficiently considered in international HRM research (see Cascio, 2012). To compile the population listings, each country followed a labour-intensive process that incorporated a significant number of company data sources along with extensive cross-examination through web-checks and telephone interviews ${ }^{1}$. For this reason, the surveys have a very high level of representativeness, more so than other research in this field.

Domestic and foreign MNCs were included in the survey with foreign MNCs the focus here, defined as MNCs with a minimum of 500 employees worldwide with at least 100 in the host country2. The surveys used the national operation of the MNC as the unit of analysis, for which we use the shorthand 'subsidiary', and the respondent was the most senior HR person at this level ${ }^{3}$. The surveys used a structured questionnaire instrument, covering a range of aspects of $\mathrm{HRM}^{4}$. The questionnaire was primarily administered through a face-to-face interview, with an online or hard copy version used where geographical distances made this impractical (i.e. Canada). Reassuringly, we did not find any significant differences between the forms of administration, which is in line with existing research that confirms measurement equivalence between internet and hard copy questionnaires (e.g. De Beuckelear and Lievens, 2009) 
The study questionnaire drew on some established questions and measures, such as those that had been employed in the Workplace Employment Relations Surveys (WERS) series in the UK, as well as incorporating new questions emanating from previous case study research on MNCs in Europe (e.g. Almond and Ferner, 2006). The instrument was co-created by the national teams: initial interactions between the UK and Canadian teams were followed by a series of virtual and face-to-face exchanges with the Irish and Spanish researchers. Core questions were agreed upon, with some alterations to questions and options required to take account of cultural idiosyncrasies. The survey instrument was extensively piloted in each country with some alterations made which were again discussed and agreed on by the researchers.

This paper draws on the data from 883 foreign-owned MNCs (UK - 258; Canada - 165; Ireland - 213; Spain - 247). Response rates varied from just under $15 \%$ to over $50 \%$ with the highest response rates coming in the countries with the smallest populations. Extensive checks for the representativeness of the achieved samples in relation to the population were carried out according to the country of origin, size and industry of the MNC. In Canada and the UK, we found that there was a mild skew towards manufacturing MNCs, in Ireland the data were slightly skewed towards large MNCs, and in Spain there was a skew towards large MNCs and those in the services industry. Consequently, the data were weighted to correct for the mild imbalances found. These weights are solely used in the descriptive statistics. These checks together with the weights further enhance the strong claim on representativeness.

The potential for constrained variation existed because the same MNC could appear in multiple national surveys. Our checks indicated that just under $13 \%$ of the cases were matched to at least one other subsidiary of the same MNC (see Authors, 2013 for greater detail). To deal with this potential issue we ran the analysis with and without these subsidiaries. Doing this had no significant impact on the models. We also controlled for when the interviews were conducted. The vast majority of the data were gathered in 2006/07 but in Spain a small number of interviews were conducted in 2008/09, 
including some following the financial crisis which may conceivably affect the results. We conducted the analysis with and without a time dummy and found that there was no significant impact on the model. Consequently, in the results section we present the estimated models without the time dummy and with all of the cases (i.e. including duplicated subsidiaries).

Like most comparative HRM studies (e.g. Pudelko and Harzing, 2007; Farndale, Brewster and Poutsma, 2008) a single respondent design was used as seeking multiple respondents would have adversely affected the response rate (as occurred in CLIRS - Marginson et al., 1993), creating significant difficulty for comparative analysis and our ability to make valid generalisations. The single respondent does raise the potential issue of common method variance (CMV) whereby bias is introduced through key variables being derived from the same respondent (Chang, Witteloostuijn and Eden, 2010). CMV is viewed as particularly problematic in behavioural research, 'in those situations in which respondents are asked to provide retrospective accounts of their attitudes, perceptions and/or behaviors' (Podsakoff, McKenzie and Lee, 2003:881). While the risks of CMV are sometimes overstated (Spector, 2006; Conway and Lance, 2010), we nevertheless took certain steps to reduce the likelihood of it occurring. Our main variables were primarily focused upon the use (or absence) of specific HR policies and practices and how the company was configured and structured. In other words, rather than drawing strongly from retrospective or perceptual measures, we focused on more objective items. Consequently, we view the potential for CMV to be low. Beyond CMV, the reliance on a single respondent can still result in measurement error. In attempting to minimise such error, we followed the advice of Wright, Gardner, Moynihan and Park (2001), through ensuring that the most knowledgeable and authoritative respondent was used; being sensitive to the information demands on the respondent; communicating in advance the kind of information that would be required, varying the scales and anchors throughout the questionnaire; and keeping the questions specific, simple and concise (Tourangeau, Rips and Raskinksi, 2000) facilitated by the project teams devoting considerable time to the wording of the items and piloting of the instrument. 


\section{Variables}

The Dependent Variables: The dependent variables were constructed from questions that asked respondents whether the subsidiary 'has provided any new practices in the following areas that have been taken up elsewhere in the worldwide company' (code 1=yes; $0=n 0$ ). If respondents answered yes, then they were asked to indicate whether the practice spread to 'a few parts of the firm', 'to major businesses', or 'taken up globally'. Due to very small cell sizes for the second and third of these options, the three options were combined into one category, creating a binary variable. We asked this question about training and development (T\&D) and employee consultation and these form our two dependent variables. These dependent variables provide a useful contrast in two respects. First, the importance of T\&D in developing capabilities, particularly the ability to generate and absorb tacit knowledge, is likely to make this issue a more strategic one than consultation in that higher levels of management are more likely to be involved in setting policy. Second, the constraints of the host country institutional setting are more marked concerning consultation practices, indicating that they are likely to face more significant institutional barriers to diffusion. Thus these two aspects of HRM practice provide a good test of whether or not the same factors explain variation in the diffusion of different HR practices.

The Explanatory Variables:

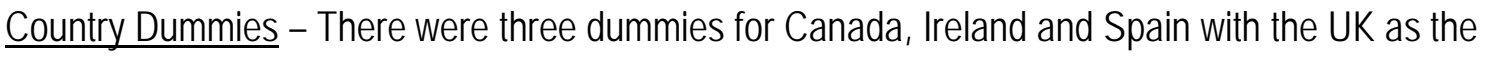
reference category.

Integrated Production - This was operationalized as a binary variable, whereby 1 represented subsidiaries in the host country that both supply other parts of the MNC with components or services 
and are supplied by other parts of the MNC and 0 incorporated the rest. We explored the possibility of using a scale for this issue (e.g. Mauri and Phatak, 2001). The problem with such measures in our context was that the precision required was likely to be challenging for a respondent in HR given that the issue of flows of components is outside their main responsibility. Consequently, in the pilot survey we tried a scale on this issue and this confirmed that there would be a substantial number of missing cases for this variable; a dichotomous scale, in contrast, generated far fewer missing cases. Thus, the pragmatic decision on integrated production was to use a dichotomous question, a process that is in line with the recommended by Tourangeau, Rips and Raskinksi (2000) concerning keeping questions specific, simple and concise.

Skills - Respondents were asked about their largest occupational group (LOG). Using the Standard Occupational Classification ${ }^{5}$ we coded these qualitative data into a high skill group (comprising professional, associate professional and technical and skilled trades), an intermediate group (sales and customer service staff) and a low skill group (mainly operatives with some in administrative, personal care and elementary occupations). The high skill and intermediate skill groups are included as dummies, leaving the low skill group as the comparator.

$\underline{\text { HR Network Intensity - To indicate HR network intensity we derived a composite measure of four }}$ mechanisms (regular meetings, international conferences, task forces and virtual groups) that enable HR managers to be brought together across borders (face-to-face and/or electronically). Respondents were asked whether these mechanisms were utilised and how frequently they occurred. The resulting variable measures how many of these elements were used at least annually, taking on values between 0 and 4. 


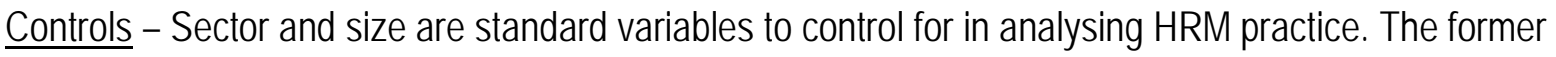
is a dummy for the service sector (with manufacturing and other production as the reference category). Size is also a dummy whereby $1=$ subsidiaries of 1,000 or more employees and $0=100-999$ employees. A further control captures the impact of US ownership ( $1=$ US MNCs; $0=$ others $)$ given that US MNCs have been shown to have a centralised mode of operation that narrows the scope for subsidiary actors to instigate RD (Edwards et al. 2005). The next set of controls relate to the nature of the product and corporate structures and include dummy variables for whether the product is adapted to national markets (as opposed to being standardised across countries); whether there are global business functions; and whether there is an international HR policy-making committee. Finally, we control for the presence of a union in the national operations ${ }^{6}$ since union presence might shape the perceptions of senior management as to how innovative the subsidiary can be (Edwards and Tempel, 2010).

\section{Results}

Descriptive Statistics

The frequencies and correlations between all of the variables appear in Tables 1 and 2 .

\section{Tables 1 and 2 here}

The pattern for the dependent variables shows that T\&D practices are more commonly diffused from subsidiaries than consultation practices. For both issues the UK subsidiaries are most frequently the source of new practices taken up elsewhere, followed by, in order, Canadian, Irish and Spanish. There are some similarities across the four countries regarding the explanatory variables, namely that trading linkages between subsidiaries and the rest of the firm constitute close to half of all subsidiaries in each country and that the low skill group is the most frequent in all nations. The degree to which the subsidiary is embedded in HR networks differs, however, with Canadian subsidiaries more commonly having connections to parts of the HR function in other countries and the Spanish least common. 


\section{Regression Analysis}

We conducted binary logistic regression on the two dependent variables, the RD of T\&D and consultation practices (see Table 3). With list-wise deletion the $N$ falls from 883 to 741 and 738 in the two models. The coefficients, standard errors, significance levels and average partial effects of each variable together with the fit statistics of the model are in Table 3. The variables are entered in two blocks, the main independent variables and then the controls. Both of the estimated models are significant at the $1 \%$ level.

\section{Table 3 here}

We now take each set of variables in turn. British subsidiaries are significantly more likely than those in Spain and Ireland to be the source of RD for both T\&D and consultation, whilst there were no significant differences between Canada and the UK. This supports hypotheses $1 \mathrm{a}, 1 \mathrm{~b}$ and $1 \mathrm{c}$. The probability that the Irish and Spanish subsidiaries provide new practices in T\&D is on average 15 and 17 percentage points respectively lower than in British subsidiaries. For consultation practices the respective figures are 7 and 9 percentage points lower.

The impact of trading linkages is consistent and significant across both models, with those subsidiaries acting as a supplier and recipient of components and services more likely to be the origins of RD. Hence, hypothesis $2 \mathrm{a}$ is supported. Other things equal, the probability that integrated subsidiaries provide new practices in T\&D is on average 8 percentage points higher than in other subsidiaries; for consultation practices, the probability was 7 percentage points higher. The impact of workforce skills did vary across the two models. For T\&D, subsidiaries in which the LOG is a high or intermediate skilled group are significantly more likely to report RD than those in which it is comprised of low skill workers. However, no significant differences were found for consultation practices meaning hypothesis $2 \mathrm{~b}$ is partially supported. The probability that high skill and intermediate skill subsidiaries 
provide T\&D practices is on average 9 and 14 percentage points respectively higher than in low skill subsidiaries.

Turning to the impact of HR network intensity, we find that having a range of forms of networking has a positive and significant effect on both models, supporting $\mathrm{H} 3$. Other things equal, using one more aspect of HR networking is associated with an average increase of 5 percentage points in the probability that subsidiaries provide new T\&D practices. The equivalent figure for consultation is 3 percentage points. Thus in both models, the higher the intensity of the HR networks, the greater the probability of RD.

Some of the controls were significant. Subsidiaries were more likely to be the source of reverse diffusion in training where they are large, the main product or service is standardised across countries rather than adapted, and where no unions are present. For consultation, subsidiaries in the service sector were less likely than those in manufacturing to be the source of reverse diffusion. The other controls were significant in neither model.

\section{Discussion and Conclusion}

The unique nature of the cross-national research design, particularly the comprehensive and representative dimensions of the surveys together with the closely coordinated process in which they were designed and implemented, have positioned us to go beyond what others studying the RD of HRM practices have been able to do. The primarily case-based literature had revealed much about the process through which RD occurs but had only hinted at factors that explain where it is most likely to happen. The data show that some subsidiaries of MNCs do indeed help the wider firm to 'draw on a diversified locational portfolio of capabilities' (Cantwell and Zhang, 2009) in HR, but far from all of them do so. This paper breaks new ground in explaining this variation.

Overall, there is strong support for our hypotheses; all three sets of factors have a significant impact on at least one of the two HR areas investigated. This vindicates our contention that there are 
multiple factors at different levels which shape whether subsidiaries engage in the RD of HR practices. In adopting an approach using multiple factors, we are following a well-established tradition within this broad field. 'Eclectic' approaches have been used within the field of international business to explain why firms internationalise (Dunning, 1988) and their choice of entry mode (Hill, Hwang and Kim, 1990). In relation to strategic international human resource management, Schuler, Dowling and De Cieri (1993) use 'several theoretical bases' to develop their 'integrative framework' while Taylor, Beechler and Napier (1996) draw on both the resource-based view of the firm and resource dependence theory to develop an 'integrative model'. More specifically to do with the transfer of HR practices in MNCs, Almond and Ferner (2006) emphasise the influence of both institutional and micro-political factors, while Bjorkman and Lervik (2007: 320) see transfer as 'a social process where the governance mechanisms used by the MNC, characteristics of the subsidiary HR systems, the social relationship between the subsidiary and MNC headquarters, and the transfer approach taken by headquarters management will influence the outcome of the process'. Whilst the ways in which different bodies of theory and concepts are combined is distinct in each case, they share the idea that multiple theoretical constructs need to be assessed to generate a full understanding of the issue in question. The adoption of this approach here has demonstrated that the actions of those who can initiate transfer are structured by multiple influences. Specifically, they are structured by: the position of the subsidiaries within the major flows of cross-border economic activity; the nature of intra-firm inter-dependencies in production; and the mechanisms of cross-border communication within the firm. We can see the significance of each of these effects in the presence of measures of the others as providing empirical support for our approach to building an explanation of this phenomenon. As such, by using a stronger dataset that has been used hitherto, covering a wider range of countries, we have consolidated and extended our understanding of the various influences considered to affect the RD of HR practices that have emanated from previous, more exploratory, studies. 
These factors appear to be common across different areas of HR. Concerning the country effect, previous work has emphasised the importance of the national context of the country of origin in shaping the barriers to RD (Edwards et al., 2005; Thory, 2008). Further, scholarship has indicated that the perceptions of those in senior positions in the firm of the host institutional context conditions the ability of subsidiaries to generate interest in their practices (Edwards and Tempel, 2010). We have extended this understanding of the role of country context by concentrating on the position of the host country within the global economy. Depending on their centrality to the flows of global economic activity, the national operations are on more or less fertile ground for being the source of RD within the broader corporation. In other words, the ability of subsidiary actors to exert influence over HR practices diffused across MNCs is shaped by their economy's position in the global environment (Boussebaa et al., 2014). Thus our interpretation of the British subsidiaries more commonly being the source of diffused practices than their Spanish and Irish counterparts focuses on the pivotal position that they have arising from their location within an economy with strong and varied links to other economies.

The importance of inter-connections between subsidiaries is also consistent across the two issues studied. The growing inter-linkages in production and service provision within MNCs have been well documented, resulting in many MNCs constituting internationally integrated networks (Buckley, 2011; Dicken, 2011). Our results show that the more subsidiaries are interconnected with other subsidiaries, as opposed to being self-standing, the more they are likely to generate RD in HR. We have interpreted this as indicating that where subsidiaries trade with one another then these flows of components or services facilitate corresponding flows of practices from that subsidiary to other parts of the firm (e.g. Holtbrugge and Mohr, 2011). Thus where a subsidiary is more central to internationally integrated production or service provision within the corporate environment then it is also more likely to be the source of new HR practices.

The third factor under investigation concerned the mechanisms within the HR function that facilitate contact between those performing similar roles in different countries. Building on work that has 
stressed the importance of the HR function being able to identify, transfer and absorb both codifiable and tacit knowledge (Dickmann and Muller-Carmen, 2006; Kim et al., 2003), we have argued that the intensity of mechanisms that enable networking between HR managers in the worldwide company is crucial in determining whether subsidiaries are the source of RD within the MNC. The results demonstrated that the transfer of practices goes hand-in-hand with a range of cross-border channels of communication. This suggests that MNCs need both types of mechanism to handle different types of knowledge, a finding that could be pursued in further research.

Given the two distinct areas of HR investigated this suggests that these factors of the macro, corporate and functional context have a consistent impact across the function in general. The influence of some factors seems to be contingent, however. The impact of the skills variables is significant in relation to the diffusion of T\&D but not consultation. If the effect is a contingent one, then it makes intuitive sense that skills would matter more for the diffusion of T\&D practices. The non-significance on consultation raises the possibility that on some issues it is not so much that high skill subsidiaries will be those most likely to be the origins of cross-national diffusion but rather that subsidiaries will have most scope to initiate diffusion where other operations have similar activities and a skills profile. In other words, it is the relationship between the skills profile in a subsidiary and those in others that matters. This finding cautions against grand generalisations concerning the impact of influences on transfer and confirms the utility in comparing how these influences affect transfer outcomes differentially across areas of practice.

Overall, this paper has made a significant contribution to our understanding of the RD of HR practices. It has been eclectic in its approach, drawing on a range of bodies of theory to develop expectations concerning the influence of quite different factors. In this respect, we echo the conclusion of Hansen and Lovas on the related issue of technological competence development in MNCs who argued that studies that focus on a single determinant 'have yielded incomplete and potentially biased results' (2004: 820). Moreover, the large, cross-national dataset enabled us to test these expectations 
and shed fresh light on this under-explored issue. Hitherto, the impact of these macro, corporate and functional factors has been looked at in isolation or on individual companies. In this paper we have shown the significant impact on each of these factors even in the presence of the others and been able to distinguish between effects that are common to both issues and those which are particular to one of them. Whitley (2009) is evidently right to argue that the development of novel capabilities should not simply be assumed. Indeed, the ability of actors in subsidiaries to share novel practices, thereby helping the MNC to realise benefits from the diversity of settings in which it operates, is at least to some extent structured according to where they sit within the global economy, the production system of the firm and the nature of relationships in the HR function. There are practical implications of this. The role of actors is, of course, crucial; transfer from subsidiaries will not happen spontaneously but rather is dependent on actors' intentions (Chung, 2014) and interests (Edwards, 1998). However, it is clear from this paper that the preferences of actors are structured and conditioned by contextual and corporate factors. In particular, the ability of subsidiary actors to initiate the transfer of practices is facilitated or constrained by their national context, their position within the production network of the multinational and the corporate channels through which transfer may operate.

There are of course some limitations which may be addressed in future research. First, although we took the suggested steps to minimise CMV and measurement error from using a single respondent, future research could pursue the matching of respondents between subsidiaries and corporate $\mathrm{HQ}$ within the same firm. Second, while the $\mathrm{R}^{2} \mathrm{~s}$ are broadly in line with other studies (Yang et al., 2008), the proportion of the variation that the models have explained is modest. Previous research has pointed to the crucial role of the power and interests of those in key positions in shaping whether reverse diffusion occurs and our research design is not capable of addressing these aspects. Third, it is possible that there is variation within subsidiaries in terms of the origin of the practices that are diffused. It may be that some regions of countries, or some types of operating unit, are more commonly the source of diffused practices. A design that allows for comparisons between the sites of multi-site 
subsidiaries would be the ideal way to investigate this. Fourth, due to the data collected here being part of a larger study investigating employment relations issues in MNCs, the single-respondent approach and the organisational level of the study (i.e. answering for all subsidiaries in a host country) we were constrained somewhat by the depth we could go into here. We recommend future research on this topic explore the feasibility of multiple respondents at multiple levels of the firm, perhaps permitting multi-item scales to be utilised. Fifth, an additional line of enquiry that could be pursued would be to explore countries with quite different institutional environments. All four countries here allow considerable flexibility and scope for experimentation in practices. An extension to this research would be to introduce countries with more cohesive labour market institutions that present significant constraints on the actions of MNCs. This would allow for an investigation of the way in which contrasting institutional frameworks condition the scope for RD. Finally, these findings are of course only in the field of HRM and future research could usefully seek to compare the influences on reverse transfer across different areas of management practice. 


\section{References}

Almond, P. (2011). 'The sub-national embeddedness of international HRM', Human Relations, 64, pp. $531-551$.

Almond, P. and Ferner, A. (2006). American multinationals in Europe: Managing employment relations across national borders, Oxford: Oxford University Press.

Amable, B. (2003). The diversity of modern capitalism. Oxford: Oxford University Press.

Arthurs, H. (2000). 'The hollowing out of corporate Canada?' In J. Jenson and B. de Sousa Santos (eds), Globalizing institutions, pp. 29-51. Burlington, VT: Ashgate.

Arthurs, H. (2009). 'The hollowing out of corporate Canada: Implications for transnational labor law, policy and practice', Buffalo Law Review, 57, pp. 781-801.

Barrett, M., Cooper, D.J. and Jamal, K. (2005). 'Globalization and the coordinating of work in multinational audits', Accounting, Organizations and Society, 30, 1, pp. 1-24.

Barry, F. (2004). 'Export-platform foreign direct investment: the Irish experience', EIB Papers, 9, pp. 837.

Birkinshaw, J. (1997). 'Entrepreneurship in multinational corporations: The characteristics of subsidiary initiatives', Strategic Management Journal, 18, pp. 207-229. 
Birkinshaw, J. and Hood, N. (1998). 'Multinational subsidiary evolution: Capability and charter change in foreign-owned subsidiary companies', Academy of Management Review, 23, pp. 773-795.

Birkinshaw, J., Hood, N. and Jonsson, S. (1998). 'Building firm-specific advantages in multinational corporations: the role of subsidiary initiative', Strategic Management Journal, 19, pp. 221-241.

Bjorkman, I. and Lervik, J. (2007). 'Transferring HR practices within multinational corporations', Human Resource Management Journal, 17, pp. 320-335

Boussebaa, M. (2009), 'Struggling to organize across national borders: The case of global resource management in professional service firms,' Human Relations, 62, 829-850.

Boussebaa, M., Sturdy, A. and Morgan, G. (2014). Learning from the world? Horizontal knowledge flows and geopolitics in international consulting firms. International Journal of Human Resource Management, 25, 9, 1227-1242.

Buckley, P. (2011). 'International integration and coordination in the Global Factory', Management International Review, 51, pp. 269-283.

Buckley, P. and Ruane, F. (2006). 'Foreign direct investment in Ireland: Policy implications for emerging economics', The World Economy, 29, pp. 1611-1628.

Campa, J. and Guillen, M. (1995). 'Spain: a boom from economic integration', Foreign Direct Investment and Governments: Catalyst for Economic Restructuring, 3, pp. 161-174. 
Cantwell, J. and Zhang, Y. (2009). 'The innovative multinational firm: the dispersion of creativity, and its implications for the firm and for world development'. In S. Collinson and G. Morgan (eds.) Images of the Multinational Firm, Chichester: Wiley.

Cascio,W.F. (2012). 'Methodological Issues in International HRManagement Research,' International Journal of Human Resource Management, 23, 12, pp. 2532-2545.

Chang, S.-J., Witteloostuijn, A. and Eden, L. (2010). 'From the editors: Common method variance in international business research', Journal of International Business Studies, 41, pp. 178-184.

Chung, L. (2014). 'Headquarters' managerial intentionality and reverse transfer of practices', Management International Review, forthcoming.

Clifton, J., Díaz-Fuentes, D. and Ruiz, E. (2011). Inward FDI in Spain and its policy context, Columbia FDI Profiles, December, ISSN 2159-2268.

Collings, D., McDonnell, A., Gunnigle, A. and Lavelle, J. (2010). 'Swimming against the tide: Outward staffing flows from multinational subsidiaries', Human Resource Management, 49, pp. 575-598.

Conway, J. M. and Lance, C. E. (2010) 'What reviewers should expect from authors regarding common method bias in organizational research', Journal of Business Psychology, 25, 325-334.

De Beuckelaer, A. and Lievens, F. (2009). 'Measurement equivalence of paper-and-pencil and internet organisational surveys: A large scale examination in 16 countries', Applied Psychology 58, 2, pp. 336-361. 
Desai, M. (2009). 'The decentering of the firm', The World Economy, 32, pp. 1271-1290.

Dicken, P. (2011). Global shift: Mapping the changing contours of the world economy, $6^{\text {th }}$ edn, New York: Guilford.

Dickmann, M. and Muller-Carmen, M. (2006). 'A typology of international human resource management strategies and processes', International Journal of Human Resource Management, 17, pp. 580-601.

Doz, Y., Santos, J. and Williamson, P. (2001). From Global to Metanational, Harvard Business School Press: Boston, MA.

Dunning, J. H. (1988). 'The eclectic paradigm of international production: A restatement and some possible extensions', Journal of International Business Studies, 19, pp. 1-31.

Edwards, T. (1998). 'Multinationals, labour management and the process of reverse diffusion: A case study', International Journal of Human Resource Management, 9, pp. 696-709.

Edwards, T. (2000). 'Multinationals, international integration and employment practice in domestic plants', Industrial Relations Journal, 31, pp. 115-129.

Edwards, T. (2011). 'The nature of international integration and human resource policies in multinational companies', Cambridge Journal of Economics, 35, pp. 483-498. 
Edwards, T., Almond, P., Clark, I., Colling, T.and Ferner, A. (2005). 'Reverse diffusion in US multinationals: Barriers from the American business system', Journal of Management Studies, 42, pp. 1261-1286.

Edwards, T., Edwards, P., Ferner, A., Marginson, P. and Tregaskis, O. (2010). 'Multinational companies and the diffusion of employment practices: Explaining variation across firms', Management International Review, 50, pp. 613-634.

Edwards, T. and Tempel, A. (2010). 'Reverse diffusion and national business systems: Evidence from the British and German subsidiaries of American multinationals', Journal of World Business, 45, pp. 1928.

Edwards, T., Tregaskis, O., Collings, D., Jalette, P. and Susaeta.L. (2013). 'Explaining similarities and variation across borders in control over employment practice in multinationals: Subsidiary functions, corporate structures and national systems', Industrial and Labor Relations Review, 66, 3,670-695.

Farndale, E., Brewster, C., \& Poutsma, E. (2008). 'Coordinated vs. liberal market HRM: The impact of institutionalization on multinational firms'. International Journal of Human Resource Management, 19, 11, pp. 2004-2023.

Faulconbridge, J. R. (2004). 'London and Frankfurt in Europe's evolving financial centre network', Area, 36, pp. 235-244.

Ferner, A., Belanger, J., Tregaskis, O., Morley, M. and Quintanilla, J. (2013). 'US multinationals and the control of subsidiary employment policies', Industrial and Labor Relations Review, 66, 3, 645-669. 
Ferner, A., Edwards, T. and Tempel, A. (2012). 'Power, institutions and the cross-national transfer of employment practices in multinationals', Human Relations, 65, 2, 163-187.

Frost, T. and Zhou, C. (2005). 'R\&D co-practice and "reverse" knowledge integration in multinational firms', Journal of International Business Studies, 36, pp. 676-687.

Furuya, N., Stevens, M., Bird, A., Oddou, G. and Medenhall, M. (2008). 'Managing the learning and transfer of global management competence: Antecedents and outcomes of Japanese repatriation effectiveness', Journal of International Business Studies, 40, pp. 200-215.

Govindarajan, V. and Ramamurti, R. (2011). 'Reverse innovation, emerging markets, and global strategy', Global Strategy Journal, 1, pp. 191-205.

Grossman, G., Helpman, E. and Szeidl, A. (2003). 'Optimal integration strategies for the multinational firm', National Bureau of Economic Research, Working Paper 10189.

Gunnigle, P. and McGuire, D. (2001). 'Why Ireland? A qualitative review of the factors influencing the location of US multinationals in Ireland with particular reference to the impact of labour issues', Economic and Social Review, 32, pp. 43-67

Gupta, A. and Govindarajan, V. (2000). 'Knowledge flows within multinational corporations', Strategic Management Journal, 21, pp. 473-496. 
Hakanson, L. and Nobel, R. (2001). 'Organizational characteristics and reverse technology transfer', Management International Review, 41, pp. 395-420.

Hansen, M. and Lovas, B. (2004). 'How do multinational companies leverage technological competencies? Moving from single to interdependent explanations', Strategic Management Journal, 25, pp. 801-822.

Harzing, A. and Noorderhaven, N. (2006). 'Knowledge flows in MNCs: An empricial test and extension of Gupta and Govindarajan's typology of subsidiary roles', International Business Review, 15, pp. 195214.

Heenan, D. (1979). 'The regional headquarters decision: A comparative analysis', Academy of Management Journal, 22, pp. 410-415.

Hill, C. W. L., Hwang, P. and Kim, W.C. (1990). 'An eclectic theory of the choice of international entry mode', Strategic Management Journal, 11, 2, pp. 117-128.

Holtbrugge, D. and Mohr, A. (2011). 'Subsidiary interdependenices and international human resource management practices in German MNCs: A resource-based view', Management International Review, 51, pp. 93-115.

Jensen, R. and Szulanski, G. (2004). 'Stickiness and the adaptation of organizational practices in cross-border knowledge transfers,' Journal of International Business Studies, 35, 6, 508-521. 
Kim, K., Park, J. and Prescott, J. (2003). 'The global integration of business functions: a study of multinational businesses in integrated global businesses', Journal of International Business Studies, 34, pp. 327-344.

Lazarova, M. and Tarique, I. (2005). 'Knowledge transfer upon repatriation', Journal of World Business, 40, pp. 361-373.

Marginson, P., Armstrong, P., Edwards, P.and Purcell, J. with Hubbard, N. (1993). The control of industrial relations in large companies. Warwick Papers in Industrial Relations, No. 45, Coventry: IRRU.

Martínez Lucio, Miguel. 1998. 'Spain: Regulating Employment and Social Fragmentation', in Anthony Ferner and Richard Hyman, eds., Changing Industrial Relations in Europe, Oxford: Blackwell.

Mauri, A.J. and Phatak, A.V. (2001). 'Global integration as inter-area product flows: the internalization of ownership and location factors influencing product flows across MNC units', Management International Review, 41, pp. 233-249.

McDonnell, A., Lavelle, J. and Gunnigle, P. (2014). 'Human Resource Management in Late Industrialising Economies: Evidence from Ireland', Management International Review, 54, 3, pp.361380..

Michailova, S. and Mustaffa, Z. (2012). 'Subsidiary knowledge flows in multinational corporations: Research accomplishments, gaps, and opportunities,' Journal of World Business, 47, 3, pp. 383-396. 
Minbaeva, D. (2007). 'Knowledge transfer in multinational corporations', Management International Review, 47, 4, pp. 567-593.

Murtha, T. and Lenway, S. (1994). 'Country capabilities and the strategic state: How national political institutions affect multinational corporations' strategies', Strategic Management Journal, 15, pp. 113129.

Nohria, N. and Ghoshal, S. (1997). The differentiated network: Organizing multinational corporations for value creation. San Francisco: Jossey-Bass.

Oddou, G., Osland, J. and Blakeney, R. (2008). 'Repatriating knowledge: Variables influencing the "transfer" process', Journal of International Business Studies, 40, pp. 181-199.

O'Malley, E. (1992). 'Problems of industrialisation in Ireland', in J. Goldthorpe and C. Whelan (eds.), The development of industrial society in Ireland. New York: Oxford University Press.

Podsakoff, P., MacKenzie, S. and Jeong-Yeon Lee. (2003). 'Common method biases in behavioral research: A critical review of the literature and recommended remedies', Journal of Applied Psychology, 88, pp. 879-903.

Pudelko, M. and Harzing, A.-W. (2007). 'Country-of-origin, localization, or dominance effect? An empirical investigation of HRM practices in foreign subsidiaries'. Human Resource Management, 46, 4, pp. $535-559$. 
Quintanilla, J.,Belizón, M.J., Susaeta, L. and Sánchez-Mangas, R. (2009). 'Malleability in Spain: The influence of human resource development models', in C. Hansen and Y. Lee (eds) The cultural context of human resource development. London: Palgrave Macmillan.

Quintanilla, J., Susaeta, L. and Sánchez-Mangas, R. (2008). 'The diffusion of employment practices in multinational: "Americanness" within US MNCs in Spain', Journal of Industrial Relations, 50, pp. 680696.

Rangan, S. and Sengul, M. (2009). 'Information technology and transnational integration: Theory and evidence on the evolution of the modern multinational enterprise', Journal of International Business Studies, 40, pp. 1496-1514.

Rosenzweig, P. and Nohria, N. (1994). 'Influences on human resource management practices in multinational corporations', Journal of International Business Studies, 25, pp. 229-251.

Rugman, A. and D'Cruz, J. (1993). 'The 'double diamond' model of international competitiveness: The Canadian experience', Management International Review, 33, pp. 17-39.

Rugman, A. and Oh, C. (2013). 'Why the home region matters: Location and regional multinationals', British Journal of Management, 24, 4, $463-479$.

Schuler, R., Dowling, P. and De Cieri, H. (1993). 'An integrative framework of strategic international human resource management', Journal of Management, 19, 2, pp. 419-459.

Sklair, L. (2001). The Transnational Capitalist Class, Blackwell: Oxford. 
Sullivan, D. (1992). 'Organization in American MNCs: The perspective of the European regional headquarters', Management International Review, 32, pp. 237-250.

Szulanski, G. (1996). 'Exploring internal stickiness: Impediments to the transfer of best practice within the firm', Strategic Management Journal, 17, pp. 27-43.

Spector, P. E. (2006). 'Method variance in organizational research', Organizational Research Methods, 9, 221-232.

Taylor, S., Beechler, S. and Napier, N. (1996). 'Toward an integrative model of strategic international human resource management', Academy of Management Review, 21, pp. 959-985.

Thory, K. (2008). 'The internationalisation of HRM through reverse transfer: Two case studies of French multinationals in Scotland', Human Resource Management Journal, 18, pp. 54-71.

Tourangeau, R., Rips, L.J. and Rasinski, K.A. (2000). The Psychology of Survey Response. London: Cambridge Univ. Press

United Nations (2012). World investment report, New York: United Nations.

Veliyath, R. and Sambharya, R. (2011). 'R\&D investments of multinational corporations: An examination of shifts in patterns of flows across countries and potential influences', Management International Review, 51, pp. 407-428. 
Whitley, R. (2009). 'The multinational firm as a distinct organizational form', in S. Collinson and G. Morgan (eds) Images of the multinational firm, Chichester: Wiley.

Wilkinson, B., Gamble, J., Humphrey, J., Morris, J., and Anthony, D. (2001). 'The new international division of labour in Asian electronics: Work organization and human resources in Japan and Malaysia'. Journal of Management Studies, 38, 5, pp. 675-695.

Wright, P., Gardner, T., Moynihan, L. and Park.H. (2001). 'Measurement error in research on human resources and firm performance: Additional data and suggestions for future research', Personnel Psychology, 54, pp. 875-902.

Xu, D., and Shenkar, O. (2002) 'Note: Institutional distance and the multinational enterprise', Academy of Management Review, 27, 4, pp. 608-618.

Yang, Q., Mudambi, R. and Meyer, K. (2008). 'Conventional and reverse knowledge flows in multinational corporations', Journal of Management, 34, pp. 882-902. 
Table 1.Frequencies

\begin{tabular}{|c|c|c|c|c|}
\hline & UK & Canada & Ireland & Spain \\
\hline \multicolumn{5}{|l|}{ Diffusion from Subsidiaries: } \\
\hline T\&D & 49.81 & 41.27 & 31.36 & 29.58 \\
\hline Consultation & 18.31 & 15.05 & 9.99 & 8.31 \\
\hline Linkages & 55.62 & 41.01 & 48.81 & 45.70 \\
\hline \multicolumn{5}{|l|}{ Workforce Skills: } \\
\hline High & 26.19 & 24.03 & 21.25 & 22.37 \\
\hline Intermediate & 6.40 & 24.02 & 20.90 & 26.88 \\
\hline Low & 67.41 & 50.21 & 57.33 & 50.60 \\
\hline HR Network Intensity & 1.50 & 2.27 & 1.76 & 1.28 \\
\hline US owned & 40.61 & 55.44 & 42.07 & 19.83 \\
\hline Size (1000+ employees) & 40.78 & 34.36 & 23.27 & 35.25 \\
\hline Sector (services) & 48.17 & 43.34 & 55.11 & 47.27 \\
\hline Product adapted & 25.28 & 31.79 & 31.81 & 24.27 \\
\hline Global Business Functions & 68.37 & 71.15 & 62.72 & 64.06 \\
\hline International HR Policy Comm. & 53.19 & 67.00 & 57.62 & 63.47 \\
\hline Union recognition & 46.99 & 46.50 & 58.49 & 82.97 \\
\hline
\end{tabular}

Notes:

The figures are based on weighted data for each country.

The variable Network intensity measures the number of networking activities performed. It takes values from 0 to 4 and the figure reported represents the sample mean. The rest of the variables are binary indicators and the figures reported represent the percentage of incidence, i.e., the sample proportion of 1's. 
Diffusion from the Subsidiaries of Multinationals

Table 2. Correlation Matrix

\begin{tabular}{|c|c|c|c|c|c|c|c|c|c|c|c|c|c|c|c|c|c|c|c|}
\hline & Variable & 1 & 2 & 3 & 4 & 5 & 6 & 7 & 8 & 9 & 10 & 11 & 12 & 13 & 14 & 15 & 16 & 17 & 18 \\
\hline 1 & Rev. diff. in T\&D & 1,00 & & & & & & & & & & & & & & & & & \\
\hline 2 & Rev. diff. in Consultation & $0,35^{*}$ & 1,00 & & & & & & & & & & & & & & & & \\
\hline 3 & Service sector & $-0,02$ & $-0,11 *$ & 1,00 & & & & & & & & & & & & & & & \\
\hline 4 & Size ( $\geq 1000$ emps) & $0,11^{*}$ & 0,03 & 0,02 & 1,00 & & & & & & & & & & & & & & \\
\hline 5 & US ownership & 0,04 & 0,05 & $-0,04$ & $-0,12^{*}$ & 1,00 & & & & & & & & & & & & & \\
\hline 6 & Product adapted & $-0,10 *$ & $-0,07 *$ & $0,06 *$ & 0,03 & $-0,03$ & 1,00 & & & & & & & & & & & & \\
\hline 7 & Struct. in global functions & $0,07^{*}$ & $0,08^{*}$ & $-0,13^{*}$ & $-0,04$ & $0,12^{*}$ & $-0,12 *$ & 1,00 & & & & & & & & & & & \\
\hline 8 & HR internat. Committee & 0,04 & 0,01 & 0,02 & 0,05 & $0,16^{*}$ & $-0,02$ & $0,18^{*}$ & 1,00 & & & & & & & & & & \\
\hline 9 & Union recognition & $-0,10^{*}$ & 0,01 & $-0,21 *$ & $0,20 *$ & $-0,20^{*}$ & $-0,01$ & $-0,03$ & 0,01 & 1,00 & & & & & & & & & \\
\hline 10 & UK & $0,15^{*}$ & $0,11^{*}$ & $-0,05$ & 0,03 & 0,03 & $-0,03$ & 0,02 & $-0,10^{*}$ & $-0,17^{*}$ & 1,00 & & & & & & & & \\
\hline 11 & Spain & $-0,09 *$ & $-0,09^{*}$ & $0,09 *$ & $0,11 *$ & $-0,15^{*}$ & $-0,06$ & 0,00 & $0,10^{*}$ & $0,28^{*}$ & $-0,40^{*}$ & 1,00 & & & & & & & \\
\hline 12 & Ireland & $-0,07^{*}$ & $-0,06$ & $0,09 *$ & $-0,10^{*}$ & 0,01 & $0,07^{*}$ & $-0,09 *$ & $-0,04$ & $-0,01$ & $-0,34 *$ & $-0,36^{*}$ & 1,00 & & & & & & \\
\hline 13 & Canada & 0,01 & 0,04 & $-0,14^{*}$ & $-0,04$ & $0,13^{*}$ & 0,03 & $0,07^{*}$ & 0,04 & $-0,12^{*}$ & $-0,30^{*}$ & $-0,32 *$ & $-0,27^{*}$ & 1,00 & & & & & \\
\hline 14 & Linkages (both ways) & $0,09 *$ & $0,13^{*}$ & $-0,25^{*}$ & $-0,01$ & $0,09 *$ & $-0,04$ & $0,15^{*}$ & $0,12^{*}$ & 0,01 & $0,11 *$ & $-0,07 *$ & $-0,01$ & $-0,03$ & 1,00 & & & & \\
\hline 15 & LOG high skill & 0,04 & $-0,01$ & $0,23 *$ & $-0,04$ & 0,03 & 0,02 & 0,02 & 0,03 & $-0,21 *$ & 0,03 & 0,00 & $-0,02$ & $-0,01$ & $-0,01$ & 1,00 & & & \\
\hline 16 & LOG interm.Skill & 0,03 & $-0,04$ & $0,30 *$ & $-0,03$ & $-0,01$ & $-0,04$ & $-0,04$ & 0,01 & $-0,06^{*}$ & $-0,21^{*}$ & $0,16^{*}$ & 0,02 & 0,03 & $-0,20^{*}$ & $-0,27^{*}$ & 1,00 & & \\
\hline 17 & LOG low skill & $-0,06$ & 0,04 & $-0,44^{*}$ & 0,06 & $-0,02$ & 0,01 & 0,02 & $-0,03$ & $0,23 *$ & $0,15^{*}$ & $-0,13 *$ & 0,00 & $-0,02$ & $0,17^{*}$ & $-0,63^{*}$ & $-0,57^{*}$ & 1,00 & \\
\hline 18 & HR Network intensity & $0,19 *$ & $0,13^{*}$ & 0,01 & $0,11^{*}$ & $0,23 *$ & $-0,02$ & $0,19 *$ & $0,35 *$ & $-0,07^{*}$ & $-0,07^{*}$ & $-0,11 *$ & 0,03 & $0,18^{*}$ & $0,07^{*}$ & 0,03 & 0,06 & $-0,07^{*}$ & 1,00 \\
\hline
\end{tabular}


Table 3. Estimation results of logit models for reverse diffusion in T\&D and consultation

\begin{tabular}{|c|c|c|c|c|c|c|c|c|}
\hline \multirow[b]{3}{*}{$\begin{array}{l}\text { Explanatory } \\
\text { Variables }\end{array}$} & \multicolumn{4}{|c|}{ T\&D } & \multicolumn{4}{|c|}{ CONSULTATION } \\
\hline & \multicolumn{2}{|c|}{ (i) } & \multicolumn{2}{|c|}{ (ii) } & \multicolumn{2}{|c|}{ (iii) } & \multicolumn{2}{|c|}{ (iv) } \\
\hline & $\begin{array}{c}\text { Logit } \\
\text { estimates }\end{array}$ & $\begin{array}{c}\text { Average } \\
\text { partial } \\
\text { effects }\end{array}$ & $\begin{array}{c}\text { Logit } \\
\text { estimates }\end{array}$ & $\begin{array}{c}\text { Average } \\
\text { partial } \\
\text { effects }\end{array}$ & $\begin{array}{c}\text { Logit } \\
\text { estimates }\end{array}$ & $\begin{array}{c}\text { Average } \\
\text { partial } \\
\text { effects }\end{array}$ & $\begin{array}{c}\text { Logit } \\
\text { estimates }\end{array}$ & $\begin{array}{c}\text { Average } \\
\text { partial } \\
\text { effects }\end{array}$ \\
\hline Constant & $\begin{array}{l}-0.343 \\
(0.230)\end{array}$ & & $\begin{array}{l}-0.557^{* *} \\
(0.276)\end{array}$ & & $\begin{array}{l}-2.008^{* * *} \\
(0.340)\end{array}$ & & $\begin{array}{l}-2.511 * * * \\
(0.410)\end{array}$ & \\
\hline $\begin{array}{l}\text { Service } \\
\text { sector }\end{array}$ & $\begin{array}{l}-0.225 \\
(0.159)\end{array}$ & $\begin{array}{l}-0.051 \\
(0.036)\end{array}$ & $\begin{array}{l}-0.300 \\
(0.197)\end{array}$ & $\begin{array}{l}-0.064 \\
(0.041)\end{array}$ & $\begin{array}{l}-0.646 * * * \\
(0.237)\end{array}$ & $\begin{array}{l}-0.070 * * * \\
(0.025)\end{array}$ & $\begin{array}{l}-0.532 * * \\
(0.271)\end{array}$ & $\begin{array}{l}-0.055^{* *} \\
(0.028)\end{array}$ \\
\hline $\begin{array}{l}\text { Size ( } \geq 1000 \\
\text { emps) }\end{array}$ & $\begin{array}{l}0.704^{* * *} \\
(0.167)\end{array}$ & $\begin{array}{l}0.164^{* * *} \\
(0.038)\end{array}$ & $\begin{array}{l}0.551^{* * * *} \\
(0.181)\end{array}$ & $\begin{array}{l}0.120 * * * \\
(0.040)\end{array}$ & $\begin{array}{l}0.210 \\
(0.226)\end{array}$ & $\begin{array}{l}0.024 \\
(0.027)\end{array}$ & $\begin{array}{l}-0.095 \\
(0.251)\end{array}$ & $\begin{array}{l}-0.010 \\
(0.026)\end{array}$ \\
\hline $\begin{array}{l}\text { US } \\
\text { ownership }\end{array}$ & $\begin{array}{l}0.072 \\
(0.156)\end{array}$ & $\begin{array}{l}0.016 \\
(0.035)\end{array}$ & $\begin{array}{l}-0.092 \\
(0.171)\end{array}$ & $\begin{array}{l}-0.019 \\
(0.036)\end{array}$ & $\begin{array}{l}0.330 \\
(0.227)\end{array}$ & $\begin{array}{l}0.037 \\
(0.025)\end{array}$ & $\begin{array}{l}0.119 \\
(0.246)\end{array}$ & $\begin{array}{l}0.013 \\
(0.026)\end{array}$ \\
\hline $\begin{array}{l}\text { Product } \\
\text { adapted }\end{array}$ & $\begin{array}{l}-0.422 * * \\
(0.177)\end{array}$ & $\begin{array}{l}-0.094^{* *} \\
(0.038)\end{array}$ & $\begin{array}{l}-0.369 * \\
(0.190)\end{array}$ & $\begin{array}{l}-0.077^{* *} \\
(0.039)\end{array}$ & $\begin{array}{l}-0.397 \\
(0.273)\end{array}$ & $\begin{array}{l}-0.041 \\
(0.026)\end{array}$ & $\begin{array}{l}-0.262 \\
(0.285)\end{array}$ & $\begin{array}{l}-0.027 \\
(0.028)\end{array}$ \\
\hline $\begin{array}{l}\text { Struct. in } \\
\text { global func. }\end{array}$ & $\begin{array}{l}0.290 * \\
(0.175)\end{array}$ & $\begin{array}{l}0.065 * \\
(0.038)\end{array}$ & $\begin{array}{l}0.230 \\
(0.183)\end{array}$ & $\begin{array}{r}0.049 \\
(0.039)\end{array}$ & $\begin{array}{l}0.450 * \\
(0.271)\end{array}$ & $\begin{array}{l}0.047^{*} \\
(0.026)\end{array}$ & $\begin{array}{l}0.434 \\
(0.295)\end{array}$ & $\begin{array}{c}0.043 \\
(0.027)\end{array}$ \\
\hline $\begin{array}{l}\text { HR internat. } \\
\text { Committee }\end{array}$ & $\begin{array}{l}0.080 \\
(0.162)\end{array}$ & $\begin{array}{l}0.018 \\
(0.036)\end{array}$ & $\begin{array}{l}-0.068 \\
(0.183)\end{array}$ & $\begin{array}{l}-0.014 \\
(0.039)\end{array}$ & $\begin{array}{l}-0.086 \\
(0.235)\end{array}$ & $\begin{array}{l}-0.010 \\
(0.027)\end{array}$ & $\begin{array}{l}-0.189 \\
(0.271)\end{array}$ & $\begin{array}{l}-0.020 \\
(0.030)\end{array}$ \\
\hline $\begin{array}{l}\text { Union } \\
\text { Recognition }\end{array}$ & $\begin{array}{l}-0.686 * * * \\
(0.166)\end{array}$ & $\begin{array}{l}-0.157^{* * *} \\
(0.037)\end{array}$ & $\begin{array}{l}-0.509 * * * \\
(0.183)\end{array}$ & $\begin{array}{l}-0.110 * * * \\
(0.040)\end{array}$ & $\begin{array}{l}-0.063 \\
(0.229)\end{array}$ & $\begin{array}{l}-0.007 \\
(0.026)\end{array}$ & $\begin{array}{l}0.152 \\
(0.250)\end{array}$ & $\begin{array}{c}0.016 \\
(0.026)\end{array}$ \\
\hline Spain & & & $\begin{array}{l}-0.720 * * * \\
(0.227)\end{array}$ & $\begin{array}{l}-0.149 * * * \\
(0.044)\end{array}$ & & & $\begin{array}{l}-0.773^{* *} \\
(0.318)\end{array}$ & $\begin{array}{l}-0.074 * * * \\
(0.028)\end{array}$ \\
\hline Ireland & & & $\begin{array}{l}-0.843^{* * *} \\
(0.222)\end{array}$ & $\begin{array}{l}-0.171 * * * \\
(0.041)\end{array}$ & & & $\begin{array}{l}-0.933^{* * *} \\
(0.334)\end{array}$ & $\begin{array}{l}-0.086 * * * \\
(0.026)\end{array}$ \\
\hline Canada & & & $\begin{array}{l}-0.257 \\
(0.256)\end{array}$ & $\begin{array}{l}-0.053 \\
(0.052)\end{array}$ & & & $\begin{array}{l}-0.162 \\
(0.332)\end{array}$ & $\begin{array}{l}-0.017 \\
(0.033)\end{array}$ \\
\hline $\begin{array}{l}\text { Linkages } \\
\text { (both ways) }\end{array}$ & & & $\begin{array}{l}0.393 * * \\
(0.171)\end{array}$ & $\begin{array}{l}0.084^{* *} \\
(0.036)\end{array}$ & & & $\begin{array}{l}0.691^{* * *} \\
(0.250)\end{array}$ & $\begin{array}{l}0.071 * * * \\
(0.025)\end{array}$ \\
\hline $\begin{array}{l}\text { LOG } \\
\text { high skill }\end{array}$ & & & $\begin{array}{l}0.426 * * \\
(0.217)\end{array}$ & $\begin{array}{c}0.092^{*} \\
(0.047)\end{array}$ & & & $\begin{array}{l}0.022 \\
(0.321)\end{array}$ & $\begin{array}{l}0.002 \\
(0.034)\end{array}$ \\
\hline $\begin{array}{l}\text { LOG } \\
\text { interm. skill }\end{array}$ & & & $\begin{array}{l}0.668 * * * \\
(0.246)\end{array}$ & $\begin{array}{l}0.144^{* * *} \\
(0.052)\end{array}$ & & & $\begin{array}{l}0.390 \\
(0.335)\end{array}$ & $\begin{array}{l}0.045 \\
(0.041)\end{array}$ \\
\hline $\begin{array}{l}\text { HR Network } \\
\text { Intensity }\end{array}$ & & & $\begin{array}{l}0.243 * * * \\
(0.063)\end{array}$ & $\begin{array}{l}0.052 * * * \\
(0.013)\end{array}$ & & & $\begin{array}{l}0.261 * * * \\
(0.091)\end{array}$ & $\begin{array}{l}0.028 * * * \\
(0.010)\end{array}$ \\
\hline $\begin{array}{l}\mathrm{N} \\
\text { Model sig } \\
\text { Vb. int. sig. } \\
\text { McF } \mathrm{R}^{2} \\
\mathrm{C} \& U \mathrm{R}^{2}\end{array}$ & $\begin{array}{l}0.040 \\
0.071\end{array}$ & & $\begin{array}{c}741 \\
* * * \\
* * * \\
0.088 \\
0.151\end{array}$ & & $\begin{array}{l}0.032 \\
0.046\end{array}$ & & $\begin{array}{c}738 \\
* * * \\
* * * \\
0.085 \\
0.118\end{array}$ & \\
\hline
\end{tabular}

Notes: Robust standard errors in parenthesis. For the average partial effects, the standard errors have been computed through the Delta method. Vb.int.sig: significance of the variables of interest. * ${ }^{* *}$, ${ }^{\star * \star}$ represent significance at 10\%, 5\% and $1 \%$ levels, respectively. 


\section{Endnotes}

1. A detailed exposition of the research design and processes undertaken can be found in Authors et al., 2006 (Canada), Authors et al., 2007 (Ireland); Authors et al., 2008 (UK), Authors, 2010 (Spain) and Authors et al., 2013 (comparative).

2. Domestic MNCs were defined as having at least 500 employees worldwide with at least 100 in one or more countries outside of the country of origin. Due to the nature of this study on reverse diffusion, domestic MNCs are excluded in this paper.

3. Our research design placed importance on seeking information from an individual who was able to speak for the national operations in question and this was achieved in around $90 \%$ of cases. Some MNCs did not have an operational HQ at national level with HR representation and here the pragmatic solution was to seek a respondent at the largest division or site.

4. The questionnaire was translated into French and Spanish and back-translated for accuracy.

5. The Standard Occupational Classification identifies nine groups: managers; professional staff; associate professional and technical; administrative; skilled manual workers; personal care staff; sales and customer service; operatives; and elementary occupations. For full details see: http://www.ons.gov.uk/about-statistics/classifications/current/soc2010/index.html

6. We control for the existence of a recognised union in Canada, Ireland and the UK and, given the institutional differences, use the functional equivalent in Spain of the presence of a legally constituted employee representative structure. 